Biol. Stud. 2016: 10(2); 183-194 • DOI: https://doi.org/10.30970/sbi.1002.496

www.http://publications.Inu.edu.ua/journals/index.php/biology

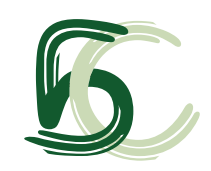

UDC: $574.583: 59(282.247 .32-477.7)$

\title{
SPECIES DIVERSITY AND SEASONAL DYNAMICS OF LITTORAL ZOOPLANKTON COMMUNITY STRUCTURES OF BAKSHALYNSKE RESERVOIR
}

\section{N. Trokhymets}

Educational and Research Center "Institute of Biology" Taras Shevchenko National University of Kyiv 64/13, Volodymyrska St., Kyiv 01601, Ukraine e-mail: realwolf@univ.kiev.ua

The results of current state of species diversity and seasonal dynamics of littoral zooplankton community structures in Bakshalynske reservoir are presented. New approaches are applied to establish the monitoring stations, and the state of methods of sampling are used in regard to the type and size of the studied artificial waterbodies. The modern trend of formation of the littoral zooplankton species diversity, all species registered for the first time in Bakshalynske reservoir. The analysis of faunal and ecological spectra littoral zooplankton, its biotopical and spatial distributions are presented. The most important grouping of species diversity in freshwater zooplankton was discovered. The results of analysis of seasonal dynamics of littoral zooplankton communities in the spring, summer and autumn in 2010 are shown. Seasonal changes in species diversity, faunal and ecological spectra biotopical and spatial distributions of quantitative indicators (density and biomass) littoral zooplankton were analyzed. The composition complex littoral zooplankton dominant in quantitative terms was also studied. It was found that its community included 11 species, 4 species of rotifers, 5 species of cladocera crustaceans and 2 types of copepods crustaceans.

Keywords: littoral zooplankton, Bakshalynske reservoir, Ukraine.

\section{INTRODUCTION}

The current problem is to study the diversity of biota in aquatic ecosystems, and changes of the functioning of aquatic communities under the influence of anthropogenic factor [3]. People build reservoirs for their own needs on many rivers In Ukraine [10]. In 2008, for normal functioning of Alexandrovske reservoir which is near the mouth of Bakshala river (a tributary of Southern Bug river) there was constructed a dam and Bakshalynske reservoir. The last one provides an additional water Aleksandrovske reservoir for the safe operation of Southern energetic complex.

Zooplankton belongs to one of the basic environmental groups of aquatic-bioindicator. Particular attention is drawn to littoral biocenoses, where zooplankton are characterized by high levels of species diversity and biological productivity. There is one work

ISSN 1996-4536 (print) • ISSN 2311-0783 (on-line) • Біологічні Студії / Studia Biologica • 2016 • Том 10/№2 • С. 183-194 
which regards Bakshaly river zooplankton studies today [8]. Concerning zooplankton of Bakshalynske reservoir, the only source of information is the original data.

Purpose - analysis of species diversity and seasonal dynamics of structuring littoral zooplankton communities in Bakshalynske reservoir.

\section{MATERIALS AND METHODS}

The object of our research were species of major groups of zooplankton: rotifers (class Eurotatoria), cladocera (class Branchiopoda, order Cladocera) and copepods (class Copepoda) crustaceans. Shell crustaceans (class Ostracoda) and larvae of bivalves in the samples are absent. Monogonontha rotifers, copepods and cladocera crustaceans were determined to the species and bdelloidea rotifers - to subclass.

Analysis of species diversity of zooplankton conducted on the basis of collected material in 2008-2010 and 2013-2015. The dynamics of the same seasonal changes was analyzed on the basis of data obtained during the season (spring, summer and autumn) in 2010 . The material selected by filtering 50 liters of water through a conical plankton net [1] within three standardized sampling stations [9] (Fig. 1), and base station - the left bank of the upper part of Bakshalynske reservoir, N 47042.625 'E 31010.332'; II - the right bank of the middle part, N 47042.483 'E 31010.945'; III - the central part of the lower reaches, N 47042.712 'E 31010.782' are presented.

Bakshalynske reservoir

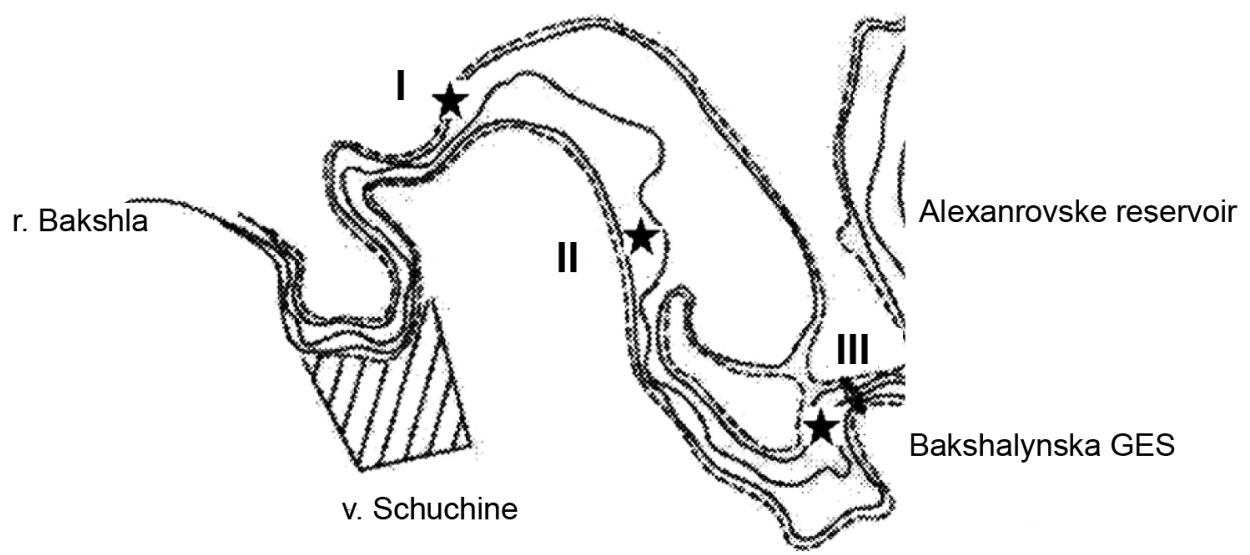

Fig. 1. Bakshalynske reservoir map-diagram with stations of integrated environmental monitoring the littoral aquatic organisms (Maplnfo program was used to made maps provided by the Institute of hydrochemistry, NAS of Ukraine)

Comment: I-III - base stations

Рис. 1. Карта-схема Бакшалинського водосховища зі станціями комплексного екологічного моніторингу літоральних гідробіонтів (виготовлена програмою MapInfo на основі карти, наданої Інститутом гідрохімії НАН України)

Примітка: I-III - базові станції

Within each station the samples were taken at various points (habitats), in the thickets of higher aquatic plants (overgrown) and clean areas of littoral macrophyte pond (not overgrown). At the stations of the upper and middle parts of Bakshalynske reservoir formations the common reed (Phragmites australis (Cav.) Trin. Ex Steud.) dominated. Lesser bulrush (Typha angustifolia L.), spiny water nymph (Najas marina L.), broad-leaved

ISSN 1996-4536 (print) • ISSN 2311-0783 (on-line) • Біологічні Студії / Studia Biologica • 2016 • Том 10/№2 • С. 183-194 
pondweed (Potamogeton nutans L.) and other macrophytes were usual among dominating species. At the bottom reservoir formations the reeds which formed the association of lesser bulrush, spiny water nymph, arrowhead (Sagittaria sagittifolia L.) and wood clubrush (Scirpus sylvaticus L.) dominated. The projective cover of higher aquatic plants increases from the top of the reservoir to its lower reaches - from 5 to $30 \%$.

For general qualitative analysis 54 samples were collected with conical net. Further processing of samples and analysis were performed on the basis of generally accepted methods. The species composition of zooplankton was identified in the laboratory due to determinants $[2,4-7]$ using stereomicroscope and microscope. Its quantitative indicators it were carried out by total revision of the entire sample in Bogorova chamber or with Henzena method. We were used criteria dominant systems Zhakkara $(J)$ and Zhakkara dominant $\left(J_{\text {dom. }}\right)$ for the comparison of zooplankton lists species [1].

\section{RESULTS AND THEIR DISCUSSION}

The original data on Bakshalynske reservoir zooplankton of the littoral zone is characterized by high species richness: - 86 species. Rotifers were represented by 45 species from subclass Monogononta and subclass Bdelloidea spp., cladocerans crustaceans -25 species, copepods crustaceans -16 species and order Harpacticoida spp. Among Monogononta rotifers the representatives of 12 families and 18 genera were marked (Table. 1). We found the highest rates of species diversity the family Brachionidae (13 species). Cladocera crustaceans are related to 5 families and 16 genera, which dominate by species representation and family Chydoridae and Daphniidae (12 and 8 species respectively). Copepods crustaceans united two families and 12 genera. Thus 15 species belonge to family Cyclopidae, and family Temoridae has only one representative - Eurytemora velox (Lilljeborg).

All littoral zooplankton species are marked for Bakshalynske reservoir for the first time, though this pond has been filled only in 2008. Taking into account the low representation of zooplankton species in Bakshala river (13 species) [8], the most majority of species of Bakshalynske reservoir zooplankton are revealed for the first time also.

In faunal spectrum littoral zooplankton species composition the rotifers (52.4\%), cladocera crustaceans $(29.0 \%)$ and copepods crustaceans (18.6\%) were registered. Monogononta rotifers from order Ploima (39 species from eight families) dominated as among rotifers and in zooplankton general. The total number of species of zooplankton representatives of all groups Ploima in percentage was about $45.3 \%$. The predominance of rotifers quality can be explained with canyon structure of Bakshalynske reservoir and with its waters reofyl conditions. Thus river zooplankton, accustomed to the flow conditions, forms the core of littoral zooplankton communities of the reservoir.

The frequency of occurrence of species within different parts of the reservoir is characterized with averages variation. Thus, 41 of 86 zooplankton species $(47.7 \%)$ were registered in the littoral of the three stations on Bakshalynske reservoir during the six-year studies. This can be explained by small size of the reservoir, long-term studies conducted and reofyl conditions of the reservoir what helped zooplankton to spread in different parts of the reservoir.

In general, the highest frequency of occurrence considering different years had the following set of species: rotifers - Asplanchna priodonta, Euchlanis dilatata, Keratella quadrata and Lecane luna; cladocera crustaceans - Alona rectangula, Bosmina longirostris and Diaphanosoma brachyurum; copepods crustaceans - Acanthocyclops americanus and Thermocyclops crassus.

ISSN 1996-4536 (print) • ISSN 2311-0783 (on-line) • Біологічні Студії / Studia Biologica • 2016 • Том 10/№2 • С. 183-194 
Table 1. Taxonomic composition of Bakshalynske reservoir littoral zooplankton

Таблиця 1. Таксономічний склад літорального зоопланктону Бакшалинського водосховища

\begin{tabular}{|c|c|c|}
\hline Temple rank taxa & Family & Genus (size of species) \\
\hline \multirow[t]{12}{*}{ Eurotatoria } & Trichocercidae & Trichocerca (1) \\
\hline & Synchaetidae & Synchaeta (3), Polyarthra (4) \\
\hline & Asplanchnidae & Asplanchna (1) \\
\hline & Lecanidae & Lecane (6) \\
\hline & Epiphanidae & Epiphanes (2) \\
\hline & Lepadellidae & Colurella (2), Lepadella (2) \\
\hline & Euchlanidae & Tripleuchlanis (1), Euchlanis (4) \\
\hline & Brachionidae & Brachionus (9), Keratella (3), Anuraeopsis (1) \\
\hline & Flosculariidae & Lacinularia (1) \\
\hline & Testudinellidae & Testudinalla (1), Pompholyx (2) \\
\hline & Filinidae & Filinia (1) \\
\hline & Hexarthridae & Hexarthra (1) \\
\hline \multirow[t]{5}{*}{ Cladocera } & Sididae & Diaphanosoma (1) \\
\hline & Daphniidae & $\begin{array}{l}\text { Daphnia (2), Simocephalus (1), Moina (2), } \\
\text { Ceriodaphnia (2), Scapholeberis (1) }\end{array}$ \\
\hline & Macrothricidae & Macrothrix (2), Ilyocryptus (1) \\
\hline & Chydoridae & $\begin{array}{l}\text { Camptocercus (1), Acroperus (1), Graptoleberis (1), } \\
\text { Chydorus (3), Disparalona (1), Pleuroxus (1), Alona (4) }\end{array}$ \\
\hline & Bosminidae & Bosmina (1) \\
\hline \multirow[t]{2}{*}{ Copepoda } & Temoridae & Eurytemora (1) \\
\hline & Cyclopidae & $\begin{array}{l}\text { Macrocyclops (1), Eucyclops (2), Colpocyclops (1), } \\
\text { Tropocyclops (1), Paracyclops (2), Ectocyclops (1), } \\
\text { Cyclops (2), Acanthocyclops (1), Megacyclops (1), } \\
\text { Mesocyclops (1), Thermocyclops (2) }\end{array}$ \\
\hline
\end{tabular}

The greatest value in grouping of zooplankton has freshwater group - 85 species $(98.8 \%)$. Invasive brackish and marine groups were represented only by one species copepods Eurytemora velox (1.2\%).

The ecological spectrum of different groups in Bakshalynske reservoirs littoral zooplankton is characterized with a predominance of pelagic groups: pelagic - 38 species ( $44.2 \%$ of all species of zooplankton), littoral-fitofyl -27 (31.4\%), benthic-fitofyl -21 (24.4\%). This can be explained with the presence in Bakshalynske reservoir reofyling conditions and increasing of its depth. These factors have contributed to the development of pelagic environmental groups.

The domination of common reed (spring and autumn overgrown habitat was not expressed), which entered sometimes in association with lesser bulrush, spiny water nymph, broad-leaved pondweed, arrowhead and wood club-rush was observed in summer on higher aquatic plants experimental stations on Bakshalynske reservoir. The rotatoria-cladoceran zooplankton complex dominated in the thickets of common reeds and in sites without water plants (Table 2). Thus, within the overgrown habitat during all 
years of studies the rotifers were presented by 27 species, cladocera -22 , copepods crustaceans -16 . The rotator complex of biocoenosis without water plants includes 23 species, cladocerans -20 , copepods -10 . Comparative analysis of lists of zooplankton in the littoral common reed and in sites without water plants showed high similarity: $J=66.2$. This can be explained by low projective cover of macrophytes and high water flow.

Table 2. Composition of zooplankton species in different littoral macrophytes formations and in sites without water plants of Bakshalynske reservoir, \%

Таблиця 2. Видовий склад літорального зоопланктону в різних формаціях макрофітів і на чистоводді Бакшалинського водосховища, \%

\begin{tabular}{|l|c|c|c|c|}
\hline Biocenoses & Group of zooplankton & Eurotatoria & Cladocera & Copepoda \\
\hline Common reed & 41.5 & 33.9 & 24.6 \\
\hline Without plants & 43.4 & 37.7 & 18.9 \\
\hline
\end{tabular}

The analysis of zooplankton trophic spectrum revealed three groups of it. The first group included representatives that eat small organisms and dead organic matter by filtering and cleaning. The variety of first order consuments reached 69 species or $80.2 \%$ of the total zooplankton species. Most of them are rotifers of 44 species, much inferior of them cladocera shellfish - 25 species, and copepods crustaceans were not represented by any one. The second group consists of zooplankton evryfags. As the result 9 species $(10.5 \%)$ were registered in this trophic group. Copepods crustaceans ( 8 species) dominated, rotifers (1 species) inferior them and crustaceans cladocera of trophic groups were absent. The third group included zooplankton predatory or second order consuments are 8 species (9.3\%). They included only types of copepods crustaceans. Value peaceful and predatory zooplankton was approximately $9 / 1$ confirming the position of environmental Lindeman law.

Analysis of the littoral zooplankton species composition in different parts of Bakshalynske reservoir showed that from its upper part to the lower one the diversity of zooplankton increase slightly: in the upper part - 58 species, in the middle -59 , in the lower - 69. High zooplankton species representation in the lower part of the reservoir associated with its small size, high flowage and low macrophytes projective covering of the reservoir littoral zone. Meantime zooplankton species lists were characterized by a high degree of similarity (Table 3), indicating the formation of a specific centre of this aquatic organisms group, which is common in different parts of the reservoir.

Table 3. A similarity of the littoral zooplankton species by Zhakkara index in different parts of Bakshalynske reservoir

Таблиця 3. Видова подібність за індексом Жаккара літорального зоопланктону різних частин Бакшалинського водосховища

\begin{tabular}{|l|c|c|c|}
\hline \multicolumn{1}{|c|}{ Part of reservoir } & Upper & Middle & Lower \\
\hline Upper & - & 69.6 & 60.8 \\
\hline Middle & 69.6 & - & 54.2 \\
\hline Lower & 60.8 & 54.2 & - \\
\hline
\end{tabular}

ISSN 1996-4536 (print) • ISSN 2311-0783 (on-line) • Біологічні Студії / Studia Biologica • 2016 • Том 10/№2 • C. 183-194 
The difference between zooplankton species lists of three experimental stations was mainly on rotifers $(J=50.0-60.0)$, which are characterized by high species diversity overall, and less on cladocera $(J=54.2-68.2)$ and copepods $(J=62.5-92.3)$ crustaceans.

The complex of dominant littoral zooplankton in quantitative terms over the years was composed with rotifers - Brachionus calyciflorus, Brachionus urceolaris, Euchlanis dilatata and Keratella quadrata; cladocera shellfish - Bosmina longirostris, Chydorus piger, Daphnia cucullata, D. longispina and Diaphanosoma brachyurum; copepods Acanthocyclops americanus and Thermocyclops crassus.

As for the seasonal dynamics of littoral zooplankton, it was investigated in 2010. Spring within all research stations was marked only in sites free of vegetation and diversity of zooplankton was presented with 14 species: rotifers - 4 species, crustacean cladocera -5 , copepods crustaceans -5 . During the daily studies in the summer in common reed sites and in the sites without water plants 37 species of littoral zooplankton were registered: rotifers - 18 species, crustaceans cladocera - 13, copepods crustaceans -6 . In autumn 30 species of zooplankton were found in sites without water plants and with reeds: rotifers -16 species, cladocera -6 , copepods crustaceans -8 .

If we consider the representation of the species, during different seasons the serious reconstruction occurred. Species diversity of littoral zooplankton increased in summer in 2.6 times in comparison with spring, and decreased in 1,2 times in autumn. Seasonal changes in species diversity of littoral zooplankton can be explained by the same reasons as in the previous year: in summer comparing with the spring the projective coverage and severity overgrown habitat significantly increase, creating more favorable conditions for the development of aquatic littoral.

The similarity of species lists, obtained in different seasons in 2010, Zhakkara index characterized by very low levels, between spring and summer $-J=18.6$, between spring and autumn $-J=22.2$, between summer and autumn $-J=36.7$. Especially low was the similarity between species composition lists of rotifers, while crustaceans, especially copepods, were characterized by more stable composition during different seasons (Table 4). The highest similarity in species composition was found when comparing summer and autumn lists of species associated with the preservation of this autumn overgrown habitat and diversity of this group of elderly aquatic organisms. Comparing with the previous year the number of species, which were met in 2010 for three seasons, increased from 2 to 5 . This happened mainly due to crustaceans: cladocera Bosmina longirostris and Chydorus sphaericus, copepods - Eucyclops serrulatus, Mesocyclops leuckarti and Thermocyclops crassus.

Table 4. Seasonal dynamics of species composition $(J)$ of different groups of the littoral zooplankton of Bakshalynske reservoir

Таблиця 4. Сезонна динаміка видового складу (J) різних груп літорального зоопланктону Бакшалинського водосховища

\begin{tabular}{|c|c|c|c|}
\hline Group Seasons & Spring and summer & Spring and autumn & Summer and autumn \\
\hline Euroratoria & 4.8 & 11.1 & 30.8 \\
\hline Cladocera & 28.6 & 22.2 & 46.2 \\
\hline Copepoda & 37.5 & 44.4 & 40.0 \\
\hline
\end{tabular}

ISSN 1996-4536 (print) • ISSN 2311-0783 (on-line) • Біологічні Студії / Studia Biologica • 2016 • Том 10/№2 • С. 183-194 
Faunal spectrum of littoral zooplankton during different seasons in 2010 was characterized by a uniform representation of groups of zooplankton in spring and in summer-autumn period - and the prevalence of rotator and rotator-cladocerans complexes (Fig. 2). This is due to the formation during spring-summer period favorable conditions for filter feeders, which dominated with rotifers and crustaceans cladocera. In autumn due to the delay of overgrown plants daying off and habitat availability, not rotting remains higher aquatic plants, the trend towards changes in the prevalence of crustacean copepods not apparent.

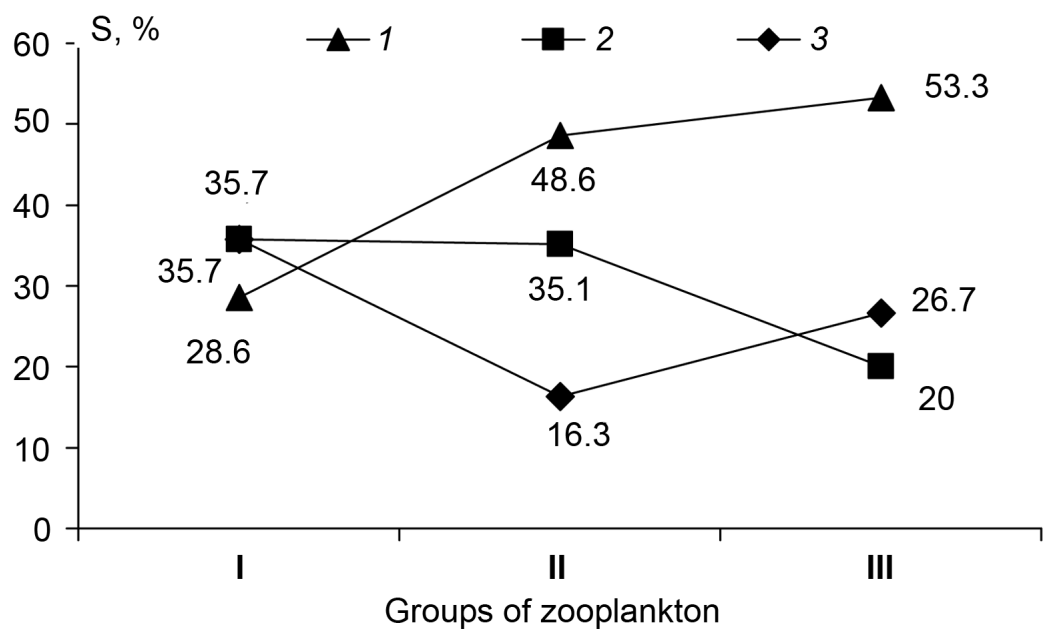

Fig. 2. Changes in faunal spectrum of Bakshalynske reservoirs littoral zooplankton in different seasons of 2010

Comments: S - size of species; 1 - rotifers 2 - cladocera crustaceans 3 - copepods crustaceans; I - spring, II - summer, III - autumn

Рис. 2. Зміни фауністичного спектра літорального зоопланктону Бакшалинського водосховища в різні сезони 2010 p.

Примітки: S - кількість видів; 1 - коловертки, 2 - гіллястовусі ракоподібні, 3 - веслоногі ракоподібні; I - весна, II - літо, III - осінь

The ecological spectrum of different groups of Bakshalynske reservoir littoral zooplankton in the spring was characterized by a predominance of pelagic groups: pelagic -10 species $(71.4 \%$ of all species of zooplankton), littoral-fitofyl $-3(21.4 \%)$, benthic-fitofyl - $1(7.2 \%)$. Summer pelagic species continued to dominate the environmental group ( 19 species $-51.4 \%$ of all species of zooplankton), but significantly increased the proportion of littoral-fitofyl (13 species $-35.1 \%$ ) and benthic-fitofyl (5 species $13.5 \%$ ) groups. In autumn the pelagic species of environmental groups also dominated by: pelagic - 18 species ( $60.0 \%$ of all species of zooplankton), littoral-fitofyl -7 species $(23.3 \%)$ and benthic-fitofyl -5 species (16.7 \%) groups. The dominance during different seasons of pelagic environmental groups and growth in summer and autumn particles of benthic-lithofyl and littoral-fitofyl groups can be explained by the formation of overgrown habitat.

Spring littoral zooplankton in quantitative terms in afternoon time was characterized by very low or low development. Its density varied within $22.6-42.4$ thousand ind. $/ \mathrm{m}^{3}$,

ISSN 1996-4536 (print) • ISSN 2311-0783 (on-line) • Біологічні Студії / Studia Biologica • 2016 • Том 10/№2 • C. 183-194 
and biomass $-0.09-0.30 \mathrm{~g} / \mathrm{m}^{3}$. Among quantitative indicators the species of rotator complex and larvae of copepods crustaceans mainly nauplia stages of development dominated (Table 5).

Table 5. Seasonal dynamics of density (thousand ind. $/ \mathrm{m}^{3}$ ) and biomass $\left(\mathrm{g} / \mathrm{m}^{3}\right)$ in different groups of the littoral zooplankton of Bakshalynske reservoir

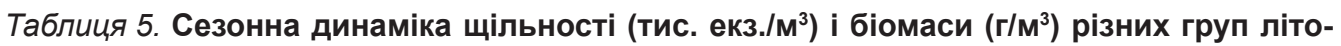
рального зоопланктону Бакшалинського водосховища

\begin{tabular}{|l|c|c|c|}
\hline \multicolumn{1}{|c|}{ Seasons } & Spring & Summer & Autumn \\
\hline Part & $11.6-15.4 /$ & $31.7-1013.6 /$ & $44.0-290.4 /$ \\
\hline Eurtotatoria & $>0.01-0.07$ & $0.13-5.77$ & $0.16-1.59$ \\
\hline Cladocera & $0.2-1.8 /$ & $2.0-149.7 /$ & $0.6-7.6 /$ \\
& $>0.01-0.06$ & $0.05-2.63$ & $0.02-0.28$ \\
\hline Copepoda & $0.6-2.0 /$ & $14.7-80.5 /$ & $3.8-55.2 /$ \\
& $0.04-0.08$ & $0.65-1.75$ & $0.11-2.07$ \\
\hline Copepodas larvae & $7.9-23.2 /$ & $74.6-792.8 /$ & $106.8-812.8 /$ \\
& $0.05-0.15$ & $0.74-7.88$ & $1.02-8.02$ \\
\hline In general & $22.6-42.4 /$ & $141.4-1910,4 /$ & $220.6-964.6 /$ \\
\hline
\end{tabular}

Comments: numerator - the density, denominator - the biomass

Примітки: чисельник - щільність, знаменник - біомаса

Summer day littoral zooplankton development was below average, average, above average and high. Its density varied within 141.4-1910.4 thousand ind./ $\mathrm{m}^{3}$, and biomass - 1.61-14.99 $\mathrm{g} / \mathrm{m}^{3}$. Among quantitative indicators in the upper and middle parts of the Bakshalynske reservoir the rotifers and copepods crustacean larvae, with a predominance copepodate stages of development, dominated. In the lower reaches of the reservoir cladocera-copepods complex, which is customary for older zooplanktotsenoziv of the reservoir, prevailed. The predominance of rotator-copepods complex in the upper part of the reservoir can be explained with very high development and inflow of the river to the reservoir two species of pelagic rotifers - Brachionus urceolaris and $B r$ calyciflorus. The share of the last one in the upper part of the reservoir was 49.1$49.7 \%$ of the whole density of zooplankton.

Autumn littoral zooplankton in daily time was characterized by below average, average and above-average development. Its density varied within 220.6-964.6 thousand ind. $/ \mathrm{m}^{3}$, and biomass $-1.93-0.48 \mathrm{~g} / \mathrm{m}^{3}$. Among quantitative indicators larvae of copepods crustaceans dominated, mainly copepodite stages of development, and representatives of the rotator complex, dominated. Prevalence of rotator complex associated with a longer period of higher aquatic plants vegetation, remains of which have formed overgrown habitat and create conditions for the development of various environmental groups of zooplankton.

Apart from the larval stage of copepods crustaceans, the spring dominant expressed within the three research stations $\left(J_{\text {dom. }}=100\right)$ was rotifers Keratella quadrata $-11.4-14.8$ thousand ind. $/ \mathrm{m}^{3}$. In summer copepodite and nauplia larval stages of copepods crustaceans dominated by density and often by biomass. Rotifers Brachionus calyciflorus and Br. urceolaris, cladocera - Bosmina longirostris, copepods - Acanthocyclops americanus

ISSN 1996-4536 (print) • ISSN 2311-0783 (on-line) • Біологічні Студії / Studia Biologica • 2016 • Том 10/№2 • С. 183-194 
form the summer dominant complex of species. In autumn larval stages of copepods crustaceans dominated by density and often by biomass. By density the representatives of the rotator complex dominated and by the biomass - rotator-copepods complex. In autumn dominant complex was formed of rotifers by Br. calyciflorus and Euchlanis dilatata, and of copepods - Mesocyclops leuckarti and Thermocyclops crassus.

We were used Zhakkara dominant index for the comparison dominant species complexes and it was recorded very low number of similarities in different seasons (Table 6). Meantime none species was not presented in dominant complexes for three seasons. Significant restructuring of littoral zooplankton dominating complex is linked with temperature conditions, significant fluctuations in the concentration of organic matter in the water and biotopical certain species.

Table 6. Seasonal dynamics of dominant species complexes $\left(\mathbf{J}_{\text {dom. }}\right)$ of the littoral zooplankton of Bakshalynske reservoir

Таблиця 6. Сезонна динаміка домінуючих комплексів видів $\left(J_{\text {дом. }}\right)$ літорального зоопланктону Бакшалинського водосховища

\begin{tabular}{l|c|c|c|}
\hline \multicolumn{1}{|c|}{ Seasons } & Spring & Summer & Autumn \\
\hline Springs & - & 0 & 0 \\
\hline Summer & 0 & - & 14.3 \\
\hline Autumn & 0 & 14.3 & - \\
\hline
\end{tabular}

Seasonal distribution of littoral zooplankton in different parts of Bakshalynske reservoirs is characterized by high and very high degree of similarity in species composition in spring, but much lower in summer and autumn (Table 7). In spring biotopical diversity was absent and littoral was characterized by the presence of sites free of vegetation. The small size of the reservoir facilitate mixing littoral and pelagic zooplankton. In the summer and autumn reed formation developed actively, which entered in association with other types of higher aquatic plants. Zooplankton species composition of the upper and middle part of the reservoir in the summer had high similarity $(J=86.7)$, in middle part - average $(J=50.0)$ and in lower part - lower $(J=38.1)$.

Table 7. Seasonal dynamics of species composition $(J)$ in the littoral zooplankton in different parts of Bakshalynske reservoir

Таблиця 7. Сезонна динаміка видового складу (J) літорального зоопланктону різних частин Бакшалинського водосховища

\begin{tabular}{|c|c|c|c|}
\hline Part of reservoir & Upper & Middle & Lower \\
\hline \multicolumn{4}{|c|}{ Spring } \\
\hline Upper & - & 61.5 & 91.7 \\
\hline Middle & 61.5 & - & 57.1 \\
\hline Lower & 91.7 & 57.1 & - \\
\hline \multicolumn{4}{|c|}{ Summer } \\
\hline Upper & - & 42.3 & 42.4 \\
\hline Middle & 42.3 & - & 39.5 \\
\hline Lower & 42.4 & 39.5 & - \\
\hline \multicolumn{4}{|c|}{ Autumn } \\
\hline Upper & - & 46.2 & 50.0 \\
\hline Middle & 46.2 & - & 41.4 \\
\hline Lower & 50.0 & 41.4 & - \\
\hline
\end{tabular}

ISSN 1996-4536 (print) • ISSN 2311-0783 (on-line) • Біологічні Студії / Studia Biologica • 2016 • Том 10/№2 • С. 183-194 
In spring 2010 littoral zooplankton was characterized by low density and very low biomass in biocenoses without water plants (Table 8).

Table 8. Seasonal dynamics of density (thousand ind./ $\left./ \mathrm{m}^{3}\right)$ and biomass $\left(\mathrm{g} / \mathrm{m}^{3}\right)$ of the littoral zooplankton in Bakshalynske reservoir

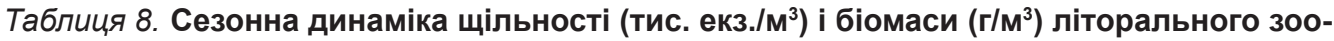
планктону Бакшалинського водосховища

\begin{tabular}{|l|c|c|c|}
\hline Seasons & Spring & Summer & Autumn \\
\hline Upper & $35.6 / 0.24$ & $993.5-1910.4 /$ & $498.4-964.6 /$ \\
& & $7.77-14.99$ & $6.12-10.48$ \\
\hline Middle & $22.6 / 0.09$ & $141.4-220.0 /$ & $220.6-249.2 /$ \\
& & $1.61-1.68$ & $2.81-2.82$ \\
\hline Lower & $42.4 / 0.30$ & $252.1-371,4 /$ & $247.8-512.8 /$ \\
\end{tabular}

Comments: numerator - the density, denominator - the biomass

Примітки: чисельник - щільність, знаменник - біомаса

Quantitative indicators were slightly higher in the upper and lower reaches, and low within the central section of Bakshalynske reservoir. The latest trend is clearly seen in summer and autumn, when in the middle of the reservoir littoral zooplankton density and biomass was developed below average. In the upper part of the waterbody the development of zooplankton density was above average and high, and the biomass - the average and above average. Sets of dominant species within the intertidal zone of the reservoir in a season had changed and most of them have a similar structure $\left(J_{\text {dom. }}=80-100\right)$.

\section{CONCLUSIONS}

Littoral zooplankton of Bakshalynske reservoir comprises 86 species: 54 species of rotifers, crustaceans cladocera - 25 , copepods crustaceans -16 . All species found in the reservoir are recorded for first time as there were no studies at all before.

Composition of faunal spectrum littoral zooplankton species was: rotifers $-52.4 \%$ cladocera crustaceans $-29.0 \%$, copepods crustaceans $-18.6 \%$.

The ecological range of different groups within the littoral zooplankton of Bahchalynske reservoirs is characterized by a predominance of the pelagic group.

Comparative analysis of lists of the littoral zooplankton in the thickets of common reed and in sites without water plants showed a high similarity: $J=66.2$.

The analysis revealed trophic spectrum of zooplankton in three groups (peaceful evryphagy and predators) with predominance of filter feeders.

A similarity of species lists obtained in different seasons of 2010, Zhakkara index was characterized by very low levels: between spring and summer $-J=18.6$, between spring and autumn $-J=22.2$, between summer and autumn $-J=36.7$.

In quantitative terms, spring littoral zooplankton noon time was characterized by very low or low development: its density varied within $22.6-42.4$ thousand ind. $/ \mathrm{m}^{3}$, and biomass $-0.09-0,30 \mathrm{~g} / \mathrm{m}^{3}$. Summer day littoral zooplankton development was below average, average, above average and high. Its density varied within 141.4-1910.4 thousand ind. $/ \mathrm{m}^{3}$, and biomass $-1.61-14.99 \mathrm{~g} / \mathrm{m}^{3}$. At middle day time, autumn littoral zooplankton

ISSN 1996-4536 (print) • ISSN 2311-0783 (on-line) • Біологічні Студії / Studia Biologica • 2016 • Том 10/№2 • С. 183-194 
was characterized by a below average, average and above-average development. Its density varied within $220.6-964.6$ thousand ind. $/ \mathrm{m}^{3}$, and biomass $-1.93-10.48 \mathrm{~g} / \mathrm{m}^{3}$.

The structure of complex littoral zooplankton dominant in quantitative terms over the years included: the rotifers - Brachionus calyciflorus, Brachionus urceolaris, Euchlanis dilatata and Keratella quadrata; cladocera - Bosmina longirostris, Chydorus piger, Daphnia cucullata, D. Iongispina and Diaphanosoma brachyurum; copepods Acanthocyclops americanus and Thermocyclops crassus.

As a result of the creation of the reservoir more complex and diverse group of zooplankton was formed indicating a stabilization of conditions existence and a possibility of further rising waters.

1. Arsan O.M., Davidov O.A., Djachenko T.M. et al. Methods surveying of surface water studies. Kyiv: LOGOS, 2006. 408 p. (In Ukrainian).

2. Borutsky E.V., Stepanova P.A., Kos M.S. The determinant of freshwater Calanoida from USSA. Moscow: Nauka, 1991. 504 p. (In Russian).

3. Emerson J.E. Seasonal dynamics of zooplankton in Columbia - Snake River reservoirs, with special emphasis on the invasive copepod Pseudodiaptomus forbesi. Aquatic Invasions, 2015; 10(1). 25-40.

4. Kutikova P.A. Rotatoria of fauna USSA. Leningrad: Nauka, 1970. 744 p. (In Russian).

5. Manujlova E.F. Cladocerans (Cladocera) of fauna USSA. Moscow-St.Petersbourg: Nauka, 1964. 327 p. (In Russian).

6. Monchenko V.I. Gnathostomata Cyclopoida, Cyclopidae. Kyiv: Naukova Dumka, 1974. 450 p. (In Ukrainian).

7. The determinant of zooplankton and zoobenthos fresh waters of European Russia. Zooplankton. Moscow-St.Petersbourg: The organization of scientific buildings KMK, 2010. 494 p. (In Russian).

8. Parchuk G.V., Klochenko P.D. Comparative characteristics of zooplankton watercourses lower part of the Southern Bug. Gidrobiol. Journal, 1994; 30(6): 8-23. (In Ukrainian).

9. Trokhymets V. N. Methods comprehensive monitoring studies of aquatic organisms in water bodies of different types. Fisheries Science Ukraine, 2011; 1: 16-23. (In Ukrainian).

10. Trokhymets V. N. Littoral Zooplankton of the Downstream Area of Kaniv Reservoir. Biology of Inland Waters, 2014; 7(2). 154-160. (In Ukrainian).

\title{
ВИДОВЕ РІЗНОМАНІТТЯ ТА СЕЗОННА ДИНАМІКА СТРУКТУРИ УГРУПОВАНЬ ЛІТОРАЛЬНОГО ЗООПЛАНКТОНУ БАКШАЛИНСЬКОГО ВОДОСХОВИЩА
}

\author{
В. М. Трохимець \\ Навчально-науковий центр "Інститут біології" \\ Київського національного університету імені Тараса Шевченка \\ вул. Володимирська, 64/13, Київ 01601, Україна \\ e-mail: realwolf@univ.kiev.ua
}

Представлено результати дослідження сучасного стану видового різноманіття та сезонної динаміки структури угруповань літорального зоопланктону Бакшалинського водосховища. У дослідженнях було використао нові методичні підходи щодо вибору станцій моніторингу та методів відбору проб залежно від типу і розмірів штучних водойм. Проаналізовано сучасні тенденції фрормування видового розмаїття літорального зоопланктону, всі види уперше зареєстровано для Бакшалинського водосховища. Здійснено аналіз фауністичного й екологічного спектрів літорального

ISSN 1996-4536 (print) • ISSN 2311-0783 (on-line) • Біологічні Студії / Studia Biologica • 2016 • Том 10/№2 • С. 183-194 
зоопланктону, а також його біотопічного і просторового розподілів. Виявлено найбільше значення видового різноманіття в угрупованні зоопланктону прісноводної групи. Проведено аналіз сезонної динаміки угруповань літорального зоопланктону навесні, влітку й восени 2010 р. Проаналізовано сезонні зміни видового різноманіття, фрауністичного й екологічного спектрів, біотопічного і просторового розподілів, кількісних показників (щільності та біомаси) літорального зоопланктону. Досліджено склад домінуючих комплексів літорального зоопланктону за кількісними показниками. 3‘ясовано, що до його складу входило 11 видів: чотири види коловерток, п'ять видів гіллястовусих ракоподібних і два види веслоногих ракоподібних.

Ключові слова: літоральний зоопланктон, Бакшалинське водосховище, Україна.

\section{ВИДОВОЕ РАЗНООБРАЗИЕ И СЕЗОННАЯ ДИНАМИКА СТРУКТУРЫ СООБЩЕСТВ ЛИТОРАЛЬНОГО ЗООПЛАНКТОНА БАКШАЛИНСКОГО ВОДОХРАНИЛИЩА}

В. Н. Трохимец

Учебно-научный центр "Институт биологии" Киевского национального университета имени Тараса Шевченко ул. Владимирская, 64/13, Киев 01601, Украина e-mail: realwolf@univ.kiev.ua

Представлены результаты изучения современного состояния и сезонной динамики структуры сообществ литорального зоопланктона Бакшалинского водохранилища. В исследованиях были использованы новые методические подходы относительно выбора станций мониторинга и методов отбора проб в зависимости от типа и размеров искусственных водоёмов. Проанализированы современные тенденции фрормирования видового разнообразия литорального зоопланктона, все виды впервые зарегистрированы для Бакшалинского водохранилища. Проведён анализ фаунистического и экологического спектров литорального зоопланктона, а также его биотопического и пространственного распределений. Обнаружено наибольшее значение видового разнообразия в сообществах зоопланктона пресноводной группы. Проведён анализ сезонной динамики сообществ литорального зоопланктона весной, летом и осенью 2010 г. Проанализированы сезонные изменения видового разнообразия, фаунистического и экологического спектров, биотопического и пространственного распределений, количественных показателей (численности и биомассы) литорального зоопланктона. Изучен состав доминирующих комплексов литорального зоопланктона по количественным показателям. Выявлено, что в его состав входило 11 видов: четыре вида коловраток, пять видов ветвистоусых ракообразных и два вида веслоногих ракообразных.

Ключевые слова: литоральный зоопланктон, Бакшалинское водохранилище, Украина.

Одержано: 12.07.2016

ISSN 1996-4536 (print) • ISSN 2311-0783 (on-line) • Біологічні Студії / Studia Biologica • 2016 • Том 10/№2 • С. 183-194 